\title{
Zpráva z kongresu - Heart Failure 2010
}

Evropský kongres Heart Failure 2010, organizovaný Heart Failure Association při Evropské kardiologické společnosti, se konal od 29. 5. do 1. 6. $2010 \mathrm{v}$ kongresovém centru v Berlíně. Kongres probíhal tradičně ve formě přehledových přednášek, původních ústních sdělení a posterových sdělení původních vědeckých prací a kasuistik.

Odborný program byl zahájen v sobotu 29. 5. několika paralelními sekcemi a symposii. Velkou návštěvnost měla sekce Best Papers 2009/2010 and What did I miss at ESC09, AHA09 and ACC10. Šlo o přednáškový blok shrnující nejvýznamnější publikované práce za poslední rok, které se zabývaly problematikou srdečního selhání. Sekci uvedl S. Stewart z Austrálie, který komentoval nejlepší práce s problematikou ošetřovatelské péče u srdečního selhání.

Za zmínku jistě stojí další přednáška $\mathrm{A}$. A. Voorse z Nizozemska na téma biomarkery. $\mathrm{V}$ úvodu přednášky zmínil A. A. Voors význam stanovení NT-proBNP pro řízení optimální terapie srdečního selhání, komentoval výsledky subanalýzy studie TIME-CHF. ${ }^{1}$ Tato studie hodnotila dopad léčby vedené podle koncentrace NT-proBNP ve srovnání s terapií řízenou klinickým stavem nemocných s chronickým srdečním selháním ve věku nad 60 let. Tato studie neprokázala, že by intenzivní léčba vedená podle vývoje koncentrace NT-proBNP měla př́iznivější dopad na přežívání pacientů s chronickým srdečním selháním než léčba řízená symptomy. Intenzifikovaná léčba chronického srdečního selhání podle NT-proBNP byla v subanalýze TIME-CHF spojena s dosažením většího počtu pacientů užívajících beta-blokátory, inhibitory ACE a sartany, včetně zvýšení dávky. Doba sledování byla ve studii TIME-CHF pouze 18 měsíců. Z dalších biomarkerů zmínil A. A. Voors aditivní význam stanovení midregionálního fragmentu adrenomedulinu k NT-proBNP při prognostické stratifikaci pacientů $s$ chronickým srdečním selháním. Dále A. A. Voors sdělil informace o nových biomarkerech chronického srdečního selhání, které označil za New Kids on the Block: solubilní receptor ST2, růstový faktor GDF-15 a galektin-3.,3 Těmto novým biomarkerům byl věnován $\mathrm{v}$ rámci kongresu samostatný přednáškový blok. A. A. Voors rovněž hovořil o významu nových ukazatelů anemie a renálního poškození, zdůraznil význam vyšetření deficitu železa u nemocných s chronickým srdečním selháním. Z parametrů renálního poškození zmínil význam stanovení albuminu v moči a význam markerů tubulárního poškození.

Další přednášku této sekce měl C. Linde ze Švédska na téma přístrojová léčba srdečního selhání. Komentoval zejména výsledky studie MADIT-CRT, ve které byla testována hypotéza, zda je srdeční resynchronizační léčba spolu s implantabilním kardioverterem-defibrilátorem prospěšná i pro méně symptomatické pacienty třídy NYHA I a II s EFLK $\leq 30 \%$ se šírí komplexu QRS $\geq 130$ ms. ${ }^{4} \mathrm{~V}$ této studii aktivní srdeční resynchronizační léčba spolu s implantabilním kardioverterem-defibrilátorem snížila relativní riziko úmrtí a hospitalizace pro srdeční selhání o 34 \% ve srovnání pouze s ICD. Př́ínivý vliv SRL-ICD u pacientů s chronickým srdečním selháním NYHA I, II a s průměrnou EFLK 24 \% však nebyl pozorován u nemocných se šírí komplexu QRS $<150 \mathrm{~ms}$.

$\mathrm{V}$ následujícím sdělení hovořil J. McMurray o novinkách ve farmakoterapii chronického srdečního selhání. V úvodu zmiňoval studie s antagonisty adenosinu PROTECT (rolofyllin) a TRIDENT (tonapofyllin), které byly s neutrálním výsledkem testovány $\mathrm{u}$ pacientů $\mathrm{s}$ akutním srdečním selháním $\mathrm{s}$ cílem zjistit jejich nefroprotektivní potenciál. Ve studii HEAAL byla testována hypotéza, zda dávka losartanu $150 \mathrm{mg}$ denně je v léčbě chronického srdečního selhání prospěšnější než dávka 50 mg. ${ }^{5}$ V dosud publikovaných studiích losartanu u srdečního selhání (ELITE2) a pacientů po infarktu myokardu (OPTIMAAL) nebyl prokázán větši dopad léčby losartanem $\mathrm{v}$ dávce $50 \mathrm{mg}$ ve srovnání s inhibitory ACE (captopril $50 \mathrm{mg} 3 \times$ denně) na morbiditu a mortalitu nemocných. ${ }^{6}$

Vyšší dávka losartanu 150 mg denně byla ve srovnání s dávkou $50 \mathrm{mg}$ denně ve studii HEAAL spojena s významným snížením relativního rizika kombinovaného ukazatele úmrtí a hospitalizace pro srdeční selhání o $10 \%(p=0,027)$.

$\mathrm{V}$ nedělním programu zaznamenalo vysokou účast symposium na téma Hlavní komorbidity u srdečního selhání: diagnóza a terapie. Symposium uvedl J. T. Parissis z Řecka přednáškou o depresi. J. T. Parissis zdůraznil, že deprese a poruchy nálady se u pacientů s chronickým srdečním selháním vyskytují velmi často, zhoršují kvalitu života a přežívání nemocných. V léčbě deprese nemocných s chronickým srdečním selháním se doporučují behaviorální techniky, zvýšení fyzické aktivity, psychosociální podpora a z farmakoterapie moderní léky ze skupiny SSRI. Randomizované studie léčby deprese u srdečního selhání se sertralinem (SADHART-CHF) a s paroxetinem však neprokázaly žádný rozdíl $\mathrm{v}$ riziku úmrtí nebo hospitalizace pro srdeční selhání ve srovnání s placebem. ${ }^{7}$

K. Swedberg v další přednášce mluvil o výskytu, patofyziologii a významu anemie u srdečního selhání. K. Swedberg z Göteborgu zdůraznil prognostický význam anemie u srdečního selhání, s každým snížením koncentrace hemoglobinu o 10 g/l výrazně stoupá riziko úmrtí a hospitalizace. Komentoval rovněž výsledky studie FAIR-HF, kde léčbou pacientů s chronickým srdečním selháním a průkazem deficitu železa i.v. podáváním soli železa bylo dosaženo zlepšení kvality života za 24 týdnů a snížení třídy NYHA. ${ }^{8}$ Další možností je léčebné podávání erytropoetinu a jeho analog, které však bylo ve studiích pacientů s chronickým srdečním selháním spojeno se zvýšením rizika komorových tachykardií, nižším přežíváním a s podporou růstu nádorů. Bezpečnost a účinnost léčby analogy erytropoetinu jsou hlavními cíli studie RED-HF, která právě probíhá. EMEA a FDA schválily erytropoetin a jeho deriváty pouze pro léčbu symptomatické anemie u pacientů s chronickým onemocněním ledvin a nádorovými onemocněními. $\mathrm{V}$ další přednášce hovořil I. S. Anand z USA o významu ischemie u srdečního selhání. Zdůraznil význam stanovení koncentrace troponinu v prognóze ambulantních pacientů se stabilním chronickým srdečním selháním. Ve studii Val-HeFT přineslo stanovení troponinu $\mathrm{T}$ supersenzitivní metodou další prognostickou informaci u chronického srdečního selhání, troponin I u pacientů s akutním srdečním selháním se ukázal jako významný prediktor horší prognózy v registru ADHERE. ${ }^{9}$ Dále I. S. Anand zdůraznil rozdíly $\mathrm{v}$ prognóze a výsledcích různých léčebných přístupů u nemocných s ischemickým a neischemickým postižením myokardu u chronického srdečního selhání. Například z přístrojové léčby srdečního selhání více profitují pacienti s neischemickým postižením myokardu. Podobně lepší výsledky léčby byly u neischemického srdečního selhání při léčbě inhibitorem fosfodiesterázy milrinonem (studie OPTIME-CHF).$^{10}$ Dále I. S. Anand zdůraznil význam chirurgické revaskularizace př́ípadně s rekonstrukcí levé komory u pacientů se srdeční dysfunkcí (studie STICH). ${ }^{11} \mathrm{O}$ vztahu hypertenze k srdečnímu 
selhání hovořil v následující přednášce F. Zannad z Francie. Uvedl, že arteriální hypertenze je významnou příčinou srdečního selhání, které lze léčebně předcházet. Zmínil výsledky studie HYVET, kdy léčba hypertenze pomocí indapamidu, př́padně s pomocí perindoprilu u pacientů ve věku nad 80 let a systolickým tlakem krve $>160 \mathrm{~mm} \mathrm{Hg}$ s cílem dosažení TK 150/80 mm Hg byla spojena se snížením relativního rizika srdečního selhání o $64 \%{ }^{12}$ Dále hovořil F. Zannad o výsledcích analýzy akutního srdečního selhání EFICA, kdy se akutní srdeční selhání manifestovalo kardiogenním šokem u 32 \% nemocných, u pacientů s plicním edémem mělo $15 \%$ nemocných systolický TK > $160 \mathrm{~mm} \mathrm{Hg}$ a $53 \%$ pacientů s akutní exacerbací srdečního selhání mělo sTK < 160 mm Hg. Hypertenze je v anamnéze nemocných se srdečním selháním častá, ale vysoký krevní tlak se u pacientů s těžkou systolickou dysfunkcí vyskytuje vzácně. ${ }^{13}$ Vyšší tlak je u pacientů s chronickým srdečním selháním spojen s lepší prognózou a častěji je prrítomen u pacientů s chronickým srdečním selháním a zachovanou ejekční frakcí levé komory (HFPEF).

$\mathrm{Na}$ závěr tohoto bloku hovořil H. Krum z Austrálie o významu chronické obstrukční plicní nemoci u chronického srdečního selhání. Uvedl, že nepoznané srdeční selhání je časté u starších pacientů s CHOPN, odhad prevalence srdeční dysfunkce $\mathrm{u}$ pacientů s CHOPN je $25-50 \%$, naproti tomu výskyt CHOPN u pacientů s chronickým srdečním selháním je odhadován na $25-50 \%$ ambulantních nemocných a $15-25 \%$ v neselektované populaci. Př́tomnost srdečního selhání u CHOPN snižuje kvalitu života, zhoršuje funkční tř́ídu NYHA, snižuje spotřebu beta-blokátorů a zvyšuje spotřebu digoxinu. Beta-blokátory snižují mortalitu nemocných s chronickým srdečním selháním s i bez CHOPN. Jak ukázala studie CHARM, léčba bronchodilatancii spolu s beta-blokátory je spojena s lepší prognózou než léčba bronchodilatancii bez beta-blokátorů. ${ }^{14}$ Dalším významným problémem je dopad CHOPN na léčbu chronického srdečního selhání a dopad chronického srdečního selhání na léčbu CHOPN. Přitom je známo, že např́íklad podání carvedilolu je spojeno se vzestupem vrcholové exspirační rychlosti (PEFR 1/min) a že beta-blokátory obecně nemají nepř́íznivý vliv na ventilační funkce $\left(\mathrm{FEV}_{1}\right)$.

Kongres byl velice př́nosný jak kvůli získání nových informací, tak pro možnost kontaktu s lékaři - specialisty v problematice srdečního selhání. Kongres ukázal nové perspektivy diagnostiky a léčby akutního a chronického srdečního selhání. Novinky v oblasti terapie zasahují nejen do farmakoterapie, ale i do oblasti přístrojové léčby srdečního selhání. Příští evropské setkání se bude konat v Göteborgu ve dnech 29. 5.-1. 6. 2011.

MUDr. Filip Málek, Ph.D.,

Kardiologické oddělení, Nemocnice Na Homolce, Praha,

e-mail: Filip.Malek@homolka.cz
Literatura

1. Pfisterer M, Buser P, Rickli $\mathrm{H}$, et al.; TIME-CHF Investigators. BNP-guided vs symptom-guided heart failure therapy: the Trial of Intensified vs Standard Medical Therapy in Elderly Patients With Congestive Heart Failure (TIME-CHF) randomized trial. JAMA 2009;301:383-392.

2. Pascual-Figal DA, Ordoñez-Llanos J, Tornel PL, et al.; MUSIC Investigators. Soluble ST2 for predicting sudden cardiac death in patients with chronic heart failure and left ventricular systolic dysfunction. J Am Coll Cardiol 2009;54:2174-2179.

3. Rehman SU, Mueller T, Januzzi Jr JL. Characteristics of the novel interleukin family biomarker ST2 in patients with acute heart failure. J Am Coll Cardiol 2008:52:1458-1465.

4. Moss AJ, Hall WJ, Cannom DS, et al.; MADIT-CRT Trial Investigators. Cardiac-resynchronization therapy for the prevention of heart-failure events. N Engl J Med 2009;361:1329-1338.

5. Konstam MA, Poole Wilson PA, Dickstein K, et al. Design of the Heart failure Endpoint evaluation of All-Antagonist Losartan (HEAAL) study in patients intolerant to ACE-inhibitor. Eur J Heart Fail 2008;10:899-906.

6. Cohn JN, Tognoni G; Valsartan Heart Failure Trial Investigators. A randomized trial of the angiotensin-receptor blocker valsartan in chronic heart failure. N Engl J Med 2001;345:1667-1675.

7. Jiang W, O'Connor C, Silva SG, et al:; SADHART-CHF Investigators. Safety and Efficacy of Sertraline for Depression in Patients with CHF (SADHART-CHF): A randomized, double-blind, placebo-controlled trial of sertraline for major depression with congestive heart failure. Am Heart J 2008;156:437-444.

8. Anker SD, Comin Colet J, Filippatos G, et al.; FAIR-HF Trial Investigators. Ferric carboxymaltose in patients with heart failure and iron deficiency. N Engl J Med 2009;361:2436-2448.

9. Yancy CW, Chang SF, ADHERE Scientific Advisory Board and Investigators. Clinical characteristics and outcomes in patients admitted with heart failure with preserved systolic function: a report from the ADHERE database. J Card Fail 2003;9(Suppl.):S84.

10. Felker GM, Benza RL, Chandler AB, et al.; OPTIME-CHF Investigators. Heart failure etiology and response to milrinone in decompensated heart failure: results from the OPTIME-CHF study. J Am Coll Cardiol 2003;41:997-1003.

11. Jones RH, Velazquez EJ, Michler RE, et al. Coronary bypass surgery with or without surgical ventricular reconstruction. N Engl J Med 2009;360: 1705-1717.

12. Beckett NS, Peters $R$, Fletcher $A E$, et al. Treatment of hypertension in patients 80 years of age or older. N Engl J Med 2008;358:1887-1898.

13. Zannad F, Cohen-Solal A, Desnos M, et al. Clinical and etiological features, management and outcomes of acute heart failure: the EFICA cohort study. Eur Heart J 2002;4(Suppl.):579.

14. Granger BB, Swedberg K, Ekman I, et al.; CHARM investigators. Adherence to candesartan and placebo and outcomes in chronic heart failure in the CHARM programme: double-blind, randomised, controlled clinical trial. Lancet 2005;366:2005-2011.

\footnotetext{
Seznam firem inzerujících v tomto čísle

sanofi-aventis, s.r.o. ............................................................................................................................. 2. strana obálky, přebalová páska

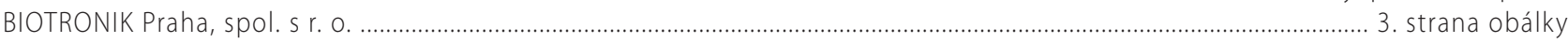

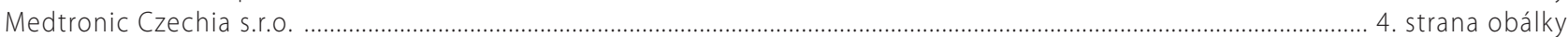

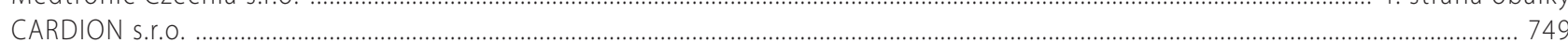

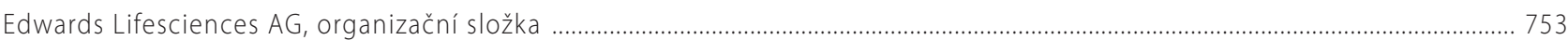

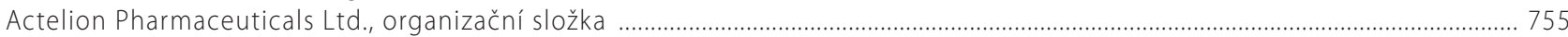

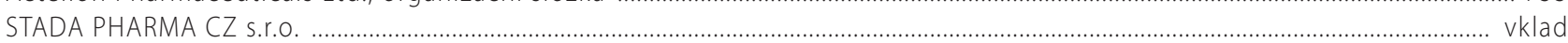

